\title{
Development of Starter Culture for the Production of African Condiments and Seasoning Agents
}

\author{
Uchenna K. Akpi*, Chukwudi I. Nnamchi, Jerry O. Ugwuanyi \\ Department of Microbiology, University of Nigeria, Nsukka, Nigeria \\ Email: *uck107@gmail.com
}

How to cite this paper: Akpi, U.K., Nnamchi, C.I. and Ugwuanyi, J.O. (2020) Review on Development of Starter Culture for the Production of African Condiments and Seasoning Agents. Advances in Microbiology, 10, 599-622.

https://doi.org/10.4236/aim.2020.1012044

Received: November 13, 2019

Accepted: December 4, 2020

Published: December 7, 2020

Copyright $\odot 2020$ by author(s) and Scientific Research Publishing Inc. This work is licensed under the Creative Commons Attribution International License (CC BY 4.0).

http://creativecommons.org/licenses/by/4.0/

Open Access

\begin{abstract}
As a process, food fermentation dates back at least 6000 years and is likely to be derived from microbial interactions of an appropriate nature. Fermentation has allowed our ancestors to survive the winter season in temperate and cooler regions and those in the tropics to survive the periods of drought by improving food shelf-life and safety. Traditional fermentation process is still used as a replacement where there is no refrigeration or other means available for food storage. In general, fermented foods can be defined as foods produced through controlled microbial growth and the conversion of food components through enzymatic actions. They are generally appreciated for characteristics such as pleasant taste, aroma, texture and improved cooking and processing properties. Microorganisms contribute to the development of characteristic properties such as taste, smell, visual appearance, texture, shelf-life and protection by virtue of their metabolic activities. Enzymes indigenous to the raw materials may play a role in enhancing these characteristics. The use of starter cultures is a hallmark of industrial food fermentation and their introduction has been followed by a continuous search to improve them. Examples of desired properties in starter cultures include robustness during manufacturing, fast growth, high biomass yield and product yield and specific organoleptic properties. Quality, safety and acceptability of traditional fermented foods may be significantly improved through the use of starter cultures selected on the basis of multifunctional considerations, also taking into account the probiotic concept and possibilities offered for improved health benefits. Focused studies toward the introduction of starter cultures for small-scale fermentations seem more than justified, and in fact, deserve the highest priority.
\end{abstract}




\section{Keywords}

Traditional Fermentation, Starter Culture, Organoleptic Properties

\section{Introduction}

\subsection{Food Fermentation}

Fermented foods are major sources of nutrition across Africa [1]. Traditional fermented food is an important part of the cultural heritage and diet that has been widely consumed since ancient times [2]. The process of fermentation involves the breakdown of organic compounds into acids or alcohol through enzymatic action of microorganisms particularly yeasts, bacteria and moulds under aerobic or anaerobic conditions [3]. It has been shown that fermentation enhances the nutritional, healthy, organoleptic and preservative properties of food [4]. As a technology that increases income sources, food availability, food diversity, reduces post-harvest losses and helps sustain food sovereignty, it plays an important role in developing economies. Most fermented foods are traditionally produced in Africa, resulting in differences in the substrate used, manufacturing conditions, packaging materials, handling and storage practices [5], and eventually significant differences in the final product.

Fermentation has been used as a means of preserving and improving the organoleptic properties of food for millennia [6]. Indeed, it has recently been revealed that more than 5000 varieties of fermented food and beverage are consumed worldwide [7]. Well-known examples include alcoholic beverages like beer and wine, dairy products such as yogurt and cheese, fermented vegetables such as pickles and sauerkraut, and fermented meat in various types of sausage. Fermentations are carried out by a variety of microorganisms: alcoholic fermentations normally involve yeast; alkaline-fermented foods normally involve a mixture of Bacillus spp.; and lactic acid bacteria are most usually found in fermentations where lactic acid is the end product while fermented legumes and cheeses involved moulds [8].

Traditional diets in Africa often lack variety and consist of large quantities of staple food (grains and tubers/root crops) with supplements of plantain, cocoyam, rice and beans, based on seasonality and availability [9] [10]. Soups eaten with staples are an essential part of the diet and may contain a wide variety of seeds, nuts, pulses and leaves [11]. The staple food supplies calories but is poor in other nutrients. Soups are key sources of protein and minerals, and one way to improve diet has been to increase the nutrient content of soups [10]. Leguminous seeds can account for up to $80 \%$ of the dietary protein and can be the only protein source for certain groups. These are consumed as meals and are commonly used as condiments to improve the taste of food in fermented form [12] [13] [14] [15]. With a high protein content, leguminous condiments can serve as a tasty supplement to sauces and soups and can be used as a substitute 
for fish or meat, especially for the very poor [10].

Food flavoring condiments are made using traditional methods of unregulated solid substrate fermentation resulting in substantial protein and carbohydrate hydrolysis [16] [17]. Besides increasing the lifespan and reducing anti-nutritional factors [12] [18] [19] [20]. Fermentation greatly enhances digestibility, nutritional value and raw seed taste [10].

Fermented foods are regarded as major dietary constituents in many developing countries, mainly because of their environmental quality, protection and conventional acceptability. Food fermentation as a process is at least 6,000 years old and is likely to be developed from sufficient microbial interactions. Fermentation has allowed our ancestors to survive the winter season in temperate and cooler regions and those in the tropics to survive the drought, improving shelf life and food safety. Over the years, fermentation has had a significant impact on dietary patterns and behaviors, on culture, and on the industrial processing and storage of food. Traditional fermentation processes also act as a replacement in the absence of refrigeration or other means of food safety [21].

Fermented foods can generally be defined as foods produced through controlled microbial growth and the conversion of food components through enzymatic actions. These are generally appreciated for characteristics such as good taste, flavor, texture and enhanced properties for cooking and storage. Microorganisms contribute to the development of characteristics such as taste, flavor, visual appearance, texture, shelf life and safety by virtue of their metabolic activity. Indigenous enzymes or enzymes generated by fermenting organisms may play a role in improving these characteristics [22]. Modern skills have been developed to monitor technological parameters during fermentation processes through trial and error. Research has also shown that the back-slop or inoculation of raw materials with residues from the previous batch speeds up the initial fermentation phase and facilitates beneficial improvements during the fermentation process. Reviews of considerable depth on traditional fermented foods have been published by Odunfa [12], Iwuoha and Eke [23] and Achi [10]. Against the background of the importance, benefits and improvement of traditional fermented condiments, the aim of this review is to assess the current state of knowledge of African fermented food condiments, with particular emphasis on the development of starter culture, for the production of safe, acceptable condiments capable of meeting the GMP requirements for global trade food.

\subsection{Substrates Used in Major African Fermented Condiments}

In Africa, many names are used for the multitude of fermented food condiments. Table 1 indicates the variety of names attributed to the items in various parts of the continent. The precise origin of these names could be traced to 1) the region or area of manufacture 2) the type of legume or oilseed used and 3) the spelling of the product by region or area or even food use. Conventional substrates for condiment production are varied and can be produced from more 
Table 1. Microorganisms associated with African fermented condiments.

\begin{tabular}{|c|c|c|c|c|}
\hline Product & $\begin{array}{c}\text { Substrate/ } \\
\text { Raw material }\end{array}$ & Microorganisms & Country & References \\
\hline Bikalga & $\begin{array}{l}\text { Roselle (Hibiscus } \\
\text { sabdariffa) }\end{array}$ & $\begin{array}{l}\text { B. subtilis, B. licheniformis, } \\
\text { B. megaterium, B. pumilus }\end{array}$ & $\begin{array}{l}\text { Burkina } \\
\text { Faso }\end{array}$ & {$[24]$} \\
\hline Dawadawa/Iru & $\begin{array}{c}\text { African } \\
\text { Locust bean }\end{array}$ & $\begin{array}{l}\text { B. pumilus, B. licheniformis, } \\
\text { B. subtilis, } \text { B. firmus, B. mojavensis, } \\
\text { B. atrophaeus, B. amyloliquefaciens, } \\
\text { Lysininbacillus sphaericus } \\
\text { Staph. Saprophyticus }\end{array}$ & $\begin{array}{l}\text { Ghana, } \\
\text { Nigeria }\end{array}$ & [25] [26] \\
\hline Ogiril Ogili & $\begin{array}{l}\text { Melon Seeds, } \\
\text { castor oilseeds, } \\
\text { pumpkin bean, } \\
\text { sesame }\end{array}$ & $\begin{array}{l}\text { B. subtilis, B. pumilus, } \\
\text { B. licheniformis, } \\
\text { B. megaterium, B. rimus, } \\
\text { Pediococcus } \text { sp., Lb. plantarum } \\
\text { Staph saprophyticus, }\end{array}$ & $\begin{array}{l}\text { West, East } \\
\text { and Central } \\
\text { Africa }\end{array}$ & {$[27]$} \\
\hline Okpeye & $\begin{array}{c}\text { Prosopis } \\
\text { Africana seeds }\end{array}$ & $\begin{array}{l}\text { B. subtilis, } B \text {. amyloliquefaciens, } \\
\text { B. cereus, B. licheniformis, } \\
\text { Micrococcus spp., B. megaterium }\end{array}$ & Nigeria & $\begin{array}{l}{[14][28]} \\
{[29][30]}\end{array}$ \\
\hline Soumbala & $\begin{array}{c}\text { African } \\
\text { Locust bean }\end{array}$ & $\begin{array}{l}\text { B. pumilus, B. atrophaeus, } \\
\text { B. amyloliquefaciens, B. mojavensis, } \\
\text { Lysininbacillus sphaericus. } \\
\text { B. subtilis, B. thuringiensis, } \\
\text { B. licheniformis, B. cereus, } \\
\text { B. badius, B. firmus, B. megaterium, } \\
\text { B.mycoides, B. sphaericus, } \\
\text { Peanibacillus alvei, } \\
\text { Peanibacillus Larvae, } \\
\text { Brevibacillus laterosporus }\end{array}$ & $\begin{array}{l}\text { Burkina } \\
\text { Faso }\end{array}$ & {$[31]$} \\
\hline$U g b a$ & $\begin{array}{l}\text { African oil } \\
\text { Bean }\end{array}$ & $\begin{array}{l}\text { B. subtilis, B. pumilus, } \\
\text { B. licheniformis, } \\
\text { Staph. saprophyticus }\end{array}$ & Nigeria & {$[32]$} \\
\hline $\begin{array}{l}\text { Owoh/Otiro } \\
\text { yam }\end{array}$ & $\begin{array}{l}\text { African Beans } \\
\text { (Stenophylis } \\
\text { stenocarpa) } \\
\text { Cotton seeds } \\
\text { (Gossypium }\end{array}$ & $\begin{array}{c}\text { Bacillius subtilis, } B \text {. licheniformis, } \\
\text { B. pumilis, Staphylococcus sp. } \\
\text { Lactobacillus jensenii, } \\
\text { Pediococcus cerevisiae, } \\
\text { Saccharomyces cerevisiae } \\
\text { Bacillus coagulans, } \\
\text { Aerococcus viridans, } \\
\text { Candida mycoderm }\end{array}$ & Nigeria & $\begin{array}{c}{[33][34]} \\
{[35]}\end{array}$ \\
\hline Mbuja & $\begin{array}{l}\text { Hibiscus } \\
\text { sabdariffa }\end{array}$ & $\begin{array}{l}\text { B. licheniformis, B. polymyxa, } \\
\text { B. laterosporus, B. cereus, } \\
\text { B. circulans, B. subtilis, } \\
\text { B. pumilus, B. brevis }\end{array}$ & Cameroon & {$[36]$} \\
\hline
\end{tabular}

NOTE: The predominant organisms are represented in bold. 
than one raw material. Almost any edible plant material may be fermented. There are numerous fermented condiments in parts of West Africa, according to the literature available [10].

\subsection{Synopsis of Some Traditional Methods Employed for the Manufacture of Condiments from Different Plant Proteins}

\subsubsection{Dawadawa}

Dawadawa is one of the most common fermented alkaline condiments produced in various parts of Africa [12] [25] [37]. It is derived from African locust bean seeds (Parkia biglobosa) and is known by different names in various parts of Africa [38]. However it can also be produced from soybeans [25]. Soy-dawadawa is a food condiment produced from the fermentation of soybean (Glycine max (L.) Merr.) seeds [39]. Dawadawa is the name widely used in Nigeria and Ghana, while in Nigeria there are other regional names such as iru, subbala, netetu and afitin or sonru [40], Burkina Faso [41], Senegal [42], and Benin [43], respectively. Dawadawa is used to enhance the taste of soups, sauces and other dishes prepared [44]. It is also reportedly often used by low-income families as a low-cost meat substitute [45] [46], In addition to its flavoring qualities, it contributes significantly to the intake of protein, essential fatty acids and group-B vitamins [47] [48] [49] [50]. The African locust bean seeds are rich in proteins (30\% - 40\%). These also provide substantial amounts of fats $(15 \%-20 \%)$, carbohydrates (10\% - 15\%), minerals (4\%) and vitamins [51] [52].

Dawadawa processing operations include cleaning, boiling, de-hulling, washing, re-cooking and spontaneous fermentation for the production of food condiment [53]. Dehulling is considered to be very tedious, extremely fuel-consuming and least hygienic of the operational phases for the conventional dawadawa production. The beans are boiled for 8 to 12 hours using firewood as fuel to dehull the seeds [54]. The boiled locust bean is then dehulled by bare feet mashing usually near riversides or using mortar and pestle [55] or rarely by minimal picking. This allows the cycle time to be partially reduced with the seeds [52]. Different studies have been done to develop the current process and make it less labor-intensive [10] [48] [56]. In an act to improve dawadawa production technology, studies have been conducted in several sub-regional West African countries, including the development of a dehuller for locust bean seed [57] [58]. The design and implementation of a dehulling device in the soumbala production process in Burkina Faso significantly reduced the cooking time from 24 hours to 6 hours [52].

\subsubsection{Okpehe}

Okpehe or Okpeye is a popular fermented soup condiment made from seeds of Prosopis africana (Guill, Perr) Taub [59] [60] [61]. The condiment is a delicious, low-cost source of protein. $P$. africana seeds are inedible to humans and animals, but when processed and fermented they can be eaten. The fermentation results in hydrolysis of proteins and oligosaccharides, as a result of the metabolic activi- 
ties of the fermenting microorganisms. For the traditional fermentation of the okpehe, the seeds of $P$. africana are boiled for $15-24 \mathrm{~h}$ until they become soft and then dehulled manually by pressing them between the palms of the hands. Thereafter, the cotyledons are washed and boiled again for $3-5 \mathrm{~h}$. They are then spread in large calabash trays or earthenware pots already lined with pawpaw leaves or other suitable leaves. The trays are then tightly wrapped in jute bags. Fermentation occurs at temperatures of $30^{\circ} \mathrm{C}-35^{\circ} \mathrm{C}$ within 3 - 5 days, resulting in a sticky, dark brown and pungent-smelling mash. The condiment is generously added to soups in many homes as a flavoring agent, but in some instances, it is also used by both urban and rural people as a meat substitute [30] [62].

\subsubsection{Ugba}

Ugba, a result of alkaline fermentation of oil bean seeds (Pentaclethra macrophylla) is very common in Southern Nigeria among Igbos and other ethnic groups [63]. The product acts as a food flavoring agent as well as a delicacy. Ugba is very rich in protein as an important nutritional item [63]. It similarly plays an economic, social and cultural role among the Igbos in the Eastern part of Nigeria. The production of ugba is usually seen as a family business. However, it has grown to become a trend that is handed over from one generation to another [63]. Its production process has been described previously as alkaline fermentation of African oil bean seeds [64] [65] [66]. Although the production method differs from one group to another and from one processor to another, a similar end product is widely manufactured in Southeast Nigeria, which usually comes with pungent ammonia-like smell [67]. A significant finding in its development is that the boiling time and the seed dehulling method differ. Obeta [68] reported $16-18 \mathrm{~h}$ of boiling, Odunfa and Oyeyiola [69] and Odunfa [48], reported initial $12 \mathrm{~h}$ boiling time, while Njoku and Okemadu [70], boiled the seeds for 5 $8 \mathrm{~h}$. Sokari and Wachukwu [71] used toasting of the bean seeds in hot $\left(\mathrm{ca} \cdot 100^{\circ} \mathrm{C}\right)$ sand and holding for a further $30 \mathrm{mins}$ at $100^{\circ} \mathrm{C}$ to dehull the seeds. Upon dehulling, the cotyledons were either cut or cooked for 30 minutes or longer. Odunfa and Oyeyiola [69] reported overnight boiling before soaking and slicing. In addition, various techniques are used in the fermentation process. Odunfa and Oyeyiola [69] stated that the cotyledons were placed in a clean pot, covered and fermented with or without salt for up to 5 days at room temperature. On the other hand, Sokari and Wachukwu [71] reported that sliced cotyledons were washed in a basket lined with banana leaves (Musa sapientum Linn.) and then wrapped (around 40 - $50 \mathrm{~g}$ of slices per wrap) using another leaf (Mallotus oppositifolius) and incubated at room temperature for 72 hours.

\subsubsection{Ogiri}

Ogiri is an alkaline fermentation of melon seeds (Citrullus vulgaris) produced in Nigeria as a food condiment. It is used for flavoring and also as a protein supplement [72]. For ogiri production, shelled melon seeds are cleaned by sorting 
and cooking for $6 \mathrm{~h}$ until soft. The cooked seeds are coated with Thaumaloccus demoelli leaves and left for 3 days to ferment. Omafuvbe et al. [72] found the $\mathrm{pH}$ of the final product to be around 7.9.

\subsubsection{Owoh}

Owoh is a food condiment with a final $\mathrm{pH}$ of about 9.0 that is popular in mid-western Nigeria and is processed by alkaline cotton seed fermentation (Gossypium hirsutum L.) [37]. Seed in its natural state is not edible because of its anti-nutritional content, especially gossypol, which inhibits digestion, but the fermented seeds are edible [34]. Owoh is prepared by boiling cotton seeds for about 2 hours until they are soft. The seeds are then soaked overnight in water and then dehulled by hand. Wrapped in banana leaves, the cotyledons are boiled again for 1 - 2 hours. The packages are placed in earthenware pots or calabash trays after draining, covered with jute sacks and allowed to ferment into Owoh for 2 - 3 days. The mash may also be ground and moulded into balls. To extend its shelf life it is smoked over charcoal [73].

\subsubsection{Bikalga}

One of the most common condiments in Burkina Faso is Bikalga, also known as dawadawa-botso in Niger Republic, datou in Mali, furundu in Sudan and mbuja in Cameroon. It is a product of Hibiscus sabdariffa $L$, alkaline fermentation commonly referred to as Roselle or sorrel [37]. Bikalga is used to flavour most dishes and is a good source of protein (22 - 30 per cent), lipids, carbohydrates, essential amino acids and fatty acids in the diet [74] [75]. Bikalga production includes seed washing, overnight cooking (12 - 24 hours) with the addition of liquid ash as a softening and alkalizing agent, followed by 3 - 4 days of fermentation, crushing, moulding, overnight steaming and finally sun drying. Bikalga is steeped in lukewarm water during the preparation of food for a few minutes and steep water is used to make stews, soups, sauces and other foods [37].

\subsection{Biochemical Changes Accompanying Fermentation}

Proteins, fats and carbohydrates are the major constituents of legumes and oilseeds used in the production of condiments. The organisms responsible for fermentation must therefore be capable of utilizing or hydrolysing these components [10].

\subsubsection{Carbohydrates}

Bacillus species have been identified as producers of carbohydrate degradation enzymes such as amylase, galactanase, galactosidase, glucosidase and fructofuranosidase [76] [77] [78] [79]. Microbial amylases hydrolyze starch into sugars that are then metabolized readily by humans. Similarly, galactanases soften the structure of the seeds and release digestive sugars [10]. Most legumes contain large quantities of non-digestible carbohydrates, including arabinogalactan, stachyosis and raffinose [12] [80]. In addition, Soybean may contain verbascose. 
These carbohydrates are associated with abdominal distention and flatulence in humans [77]. Fermentation reduces total soybean flatus [81] and groundnut [82] and maybe other seeds are used to produce condiments. Trypsin inhibitor activity of Bambara groundnut [19] was also reduced during fermentation. Consequently, fermentation of oilseeds to produce condiments usually leads to a reduction in seed antinutrient components.

\subsubsection{Proteins}

The extent of protein hydrolysis is one of the most important factors associated with changes in the texture and flavor of the substrate in most fermented high-protein products [83]. The enzymatic degradation of proteins produces soluble low molecular weight peptides and amino acids that contribute to the flavor [12] [49] [70] [84]. Good quality condiments typically come with a strong characteristic smell of ammonia and are dark in colour. Amino acids and ammonia produced as a result of protein degradation are responsible for a gradual increase in $\mathrm{pH}$ and a leveling up to 7.5 - 8.0 [14] [77] [84]. Increased pH to alkaline levels may be physiologically important for the tolerance and adaptation of fermenting microorganisms in the environment [10] and for reducing undesirable processes due to alkaline intolerant organisms. Free amino acids increase but longer fermentation results in losses of lysine or other essential amino acids [81]. This is a strong reason why fermentation is critically controlled away from traditional unregulated processes.

\subsubsection{Lipid}

Significant leguminous lipolysis yields primarily oleic, linoleic and linolenic acids [50] [85] [86]. These free fatty acids were associated with non-specific antitryptic activity, particularly oleic, linoleic and linolenic acids [81]. As such, extensive lypolysis could diminish nutritional quality. Although oil accounts for up to $40 \%$ of the legumes used in food fermentation, extensive lipolysis typically does not occur. Odunfa [12] during dawadawa production reported low levels of lipase activity in Parkia biglobosa. The same author had previously reported low lipase levels in fermentation of melon seeds [48]. Similarly, Njoku and Okemadu [70] observed minimal participation of lipase in Pentachletera macrophylla during ugba production. Low lipase activity in some fermented foods was deemed beneficial due to adverse taste problems and rancidity production [12] [48] [87].

However, there are reports of beneficial effects of lipase in the development of characteristic flavours and aroma [83] [88]. These results appear to be conflicting and require further study. An interesting area would be the effects of changes in lipid quantity and quality on the organoleptic properties of fermented condiments Darweesh et al. [89] reported that aldehydes resulting from oxidation of lipids cause off-flavour and odour problems. Nevertheless, the organic solvent treatment of fermented condiments from locust bean, melon seed and soybean showed no appreciation of the odor [90]. Not much can be said about the flavoring components of fermented vegetable proteins used as condiments, as li- 
mited research has been done on this aspect [67]. There is no doubt, however, that amines, peptides and glutamic acid all contribute to this taste [10].

\subsection{Nutritional Quality of Fermented Condiments}

Classical nutrient bioavailability evaluation methods generally involve animal models in vivo experiments. The use of proteins as a ratio of protein efficiency (PER) and the digestibility of soybean and some legumes has hardly been improved by fermentation [86] [91]. It has been documented that rats do not make better use of proteins from fermented soybean than from the cooked substrate. Nevertheless, some reports indicate otherwise. Achinewhu [85] reported that fermentation and heat treatment improved the apparent digestibility, feed quality, and protein production ratio when rats were fed on African oilseed rations diets.

Eka [17] studied the effect of fermentation on the nutrient content of locust beans and reported an increase in protein and fat when fermented, whereas the amount of carbohydrate decreased, this relative increase is due to a reduction in the percentage of carbohydrate content. Increased levels of amino acids except arginine, leucine and phenylalanine have also been reported. Similar studies have been reported for other seed legumes [12] [77] [85]. During the fermentation of melon seeds, soluble products increased and the fermented product was highly digestible. The main amino acids are alanine, lysine and glutamic acid, with small amounts of arginine and proline [13]. Improved nutritional values were attributed to increased amino acid profiles due to fermentation [10].

\section{Prospects for the Development and Use of Starter Cultures in African Fermented Seasoning}

\subsection{Starter Culture}

Starter cultures or starters are individual or mixed formulations of selected strains of microorganisms with a particular physiological capacity to turn a substrate into a food product with specific characteristics when added at specified concentrations [92] [93]. Adapted to the substrate, the typical starter facilitates improved control of the fermentation process and the predictability of its products [94]. The development, improvement and standardization of microbial starters have been driving force for the transformation of traditional food fermentations in developing countries from an "art" to a science. The development of microbial starter culture has also been a driving force for innovation in the design of equipment suitable for the hygienic processing of traditional fermented foods under controlled conditions in many developing countries.

The development of starter culture has played a pivotal role in the production of high-value products such as enzymes, microbial cultures and functional food ingredients, together with the development and improvement of bioreactor technology to control fermentation processes in developed countries. As inputs for their food processing operations, these goods are primarily manufactured in 
more advanced developing economies and are increasingly imported at high cost by less advanced developing countries.

\subsection{Traditional Approaches: Spontaneous Fermentations and Back-Slopping}

Traditional starter cultures are picked either as single or multiple strains, primarily for adaptation to the substrate or raw material. Spontaneous fermentation, i.e. processes conducted without the use of starter inoculum, have been used for centuries for food preservation and have been explained by trial and error, probably over thousands of years. Many small-scale fermentations are still performed in developing countries as spontaneous processes and some industrial processes, such as sauerkraut fermentation and traditional wine production. Different types of starter cultures, even in industrialized countries, are widely used in fermentation processes. Spontaneous fermentation is typically the result of competitive activities of a variety of contaminating microorganisms [94] [95]. The process eventually dominates those that are best adapted to the food substrate and the technical control parameters. During fermentation, the development of metabolites (e.g. organic acids) that are inhibitory to other contaminating microbes (e.g. enterobacteriaceae) may provide additional benefit. Bacteria usually dominate the early stages of fermentation processes in substrates rich in fermentable sugars due to their relatively high growth rate, followed by yeasts. Content from a previous successful batch is used in many conventional processes to promote the initiation of a new process. The initial phase of the fermentation process is shortened by this method of backslopping and the risk of failure of fermentation is reduced. Repeated use of back-slopping results in the choice of best-adapted strains, some of which may have features suitable for use as starter cultures [94] [95].

\subsection{Inoculation to Improve Process Control}

It takes a relatively long time $(24-48 \mathrm{~h})$ to initiate a spontaneous fermentation process, with a high risk of failure. During this early stage, which is linked to the lag phase of microbial growth, the contamination of raw materials, utensils and the environment by microorganisms increases slowly and competes for nutrients. Through inoculation, this step can be reduced either by back-slopping or using selected start cultures. The beneficial characteristics of the substrate, consumer expectations and technical requirements largely dictate the nature of the starter culture to be used, i.e. single-strain vs. mixed-strain culture [94] [95].

\subsection{Starter Cultures as Inoculants of Fermentation Processes}

In the fermented food sector, "Appropriate" starter cultures are widely used as inoculants, from household to industrial, low-income and low-middle-income economies [94]. These starter cultures are generally produced using a back-slopping process that uses samples from a previous batch of a fermented product as in- 
oculants [95]. The inoculation belt used in traditional fermentations in West Africa serves as a carrier of undefined fermenting microorganisms, and is one example of an appropriate starter culture [94]. It usually comprises of a woven fiber or mat or a piece of wood or woven sponge, saturated with a previous fermentation batch's "high"-quality product. To act as an inoculant, it is immersed in a new batch. The inoculation belt is used for the production of native fermented porridges, "uji" and "mawe", as well as for the production of Ghanaian beer "pito." Another example of an "appropriate" starter culture produced by back slopping is Iru. This starter culture is produced from concentrated fermented dawadawa (a result of fermented legumes), mixed with unfermented legumes, vegetables such as pepper, and cereals such as ground maize. It is preserved in a dried form and is used as an inoculant in dawadawa fermentations in West Africa [94]. In Asian countries, a variety of suitable starter cultures are used as fermentation inoculants, either in a granular form or as a pressed cake. Different names such as marcha or murcha in India, ragi in Indonesia, bubod in the Philippines, nuruk in Korea, koji in Japan, ragi in Malaysia, and Loog-pang in Thailand generally refer to these traditional mould starters. They generally consist of a mixture of moulds grown under non-sterile conditions.

\subsection{Defined Starter Cultures as Inoculants of Fermentation Processes}

Few specified starter cultures have been developed to be used as inoculants in commercial fermentation processes in developing countries. However, over the last ten years, a number of developing countries have witnessed the development and application of selected and pre-cultivated starter cultures in food fermentation. "Defined starter cultures" consist of single or mixed strains of micro-organisms [94]. It is possible to incorporate adjunct culture preparations that serve a function of food safety and preservation. Due to their ability to inhibit pathogenic or spoilage organisms, adjunct cultures do not necessarily produce fermentation acids or alter texture or taste, but are included in the defined culture. An inhibitory function is ascribed to the development of one or more products, such as hydrogen peroxide, organic acids, diacetyl and bacteriocin [6]. Generally defined cultures are produced by the maintenance and spread of pure culture under aseptic conditions. They are generally marketed in a liquid or powdered form or else as a pressed cake.

Defined starter cultures are also commonly imported by developing countries for use in the commercial production of dairy products such as yogurt, kefir, cheese and alcoholic beverages as well as in bakeries. Many of these cultures are tailored to produce specific textures and flavours. Most yogurt cultures also include probiotic strains in response to increasing consumer interest in achieving wellness through diet. Probiotics are currently produced in India, South Africa and several other countries for use as food additives, dietary supplements and for use in animal [94]. Methodologies used in these starters' design and tailoring are 
primarily the responsibility of these starters' suppliers. Monosodium glutamate and lactic acid, both used as ingredients in the food industry, are developed using defined starter cultures in less advanced developing countries.

\section{Selection of Starter Cultures and Their Application in Small-Scale Fermentations}

\subsection{Approaches and Considerations for the Selection of Pure Cultures}

Considerations for implementing household-level starter cultures must take into consideration cultural traditions, dietary habits and raw materials, and cottage-use technological conditions that vary across regions and continents. From a technical point of view, cost/benefit ratios, operational considerations and a small-scale processor's willingness to accept new approaches are crucial in any assessment of the viability of incorporating the use of starter cultures in small-scale fermentations. Therefore, for use at the artisanal level, a minimum set of standards or performance criteria should be established for the handling and maintenance of these cultures. The possibility of applying starter cultures will become attractive to the small-scale processor only if benefits, such as reduction of costs (e.g. energy), reduced fermentation times, reduced risk of spoilage (increased shelf-life), improved process control, improved sensory quality (taste, aroma, visual appearance, texture, consistency), improved safety attributes (e.g. lower risk if diarrhoea, detoxification of cassava) and reduced preparation procedures for the final product, are perceived. These are in addition to reduced need for stringent process control. Some LAB and yeast strains associated with fermented foods, such as phytic acid and phenolic compounds, can degrade antinutritional factors. Therefore, the incorporation of these organisms into starting culture can help to improve the nutritional value of foods [94].

In recent times, there has been considerable focus on the inclusion of mycotoxin-degrading strains in starter cultures. The use of mycotoxin contaminated raw materials for fermentation in developing countries presents a particular challenge in the choice of strains that can detoxify mycotoxins [94] [95] [96] [97]. In respect of their possible contribution to improving overall health and well-being, the probiotic properties of strains involved in food fermentation are also being studied.

\subsection{Selection Criteria for Starter Culture Development}

Spontaneous food fermentations are neither predictable nor controllable. Therefore, single-and mixed-strain cultures must be tested on the pilot scale before being used in small-scale operations. According to Holzapfel [94], the introduction of starter cultures in traditional small-scale fermentation should take into account considerations for improving the processing conditions and quality of the product by: 1) rapid accelerated metabolic activities (acidification or alcohol production); 2) improved and more predictable fermentation processes; 3) 
desirable sensory attributes; 4) improved safety and reduced hygienic and toxicological risks.

The primary screening is based primarily on the evaluation of candidate strains' ability to withstand the pressure conditions imposed by fermentation processes [98]. At the beginning of the process, microbial cells are impaired by osmotic pressure due to the high concentration of solutes in the fermentation medium, such as grape sugar, hydrolyzed malt or sugar cane, milk matrix proteins and lipids and vegetable sodium [99].

Cell exposition to such hypertonic conditions leads to an efflux of water from the cell, decreasing both turgor pressure and water availability [100]. It causes main microbial metabolism enzymes to be inactivated, in addition to increasing toxic ion concentration and eventually cell death. Nonetheless, through natural selection it is possible to distinguish strains that are well suited to these stressful environments [98]. These resistant strains respond to osmotic stress by accumulating specific solutes, such as potassium ions, amino acids (e.g., glutamine, glutamate, proline, $y$-aminobutyrate, and glycinebetaine) and sugar (sucrose, trehalose, and glucosylglycerol), which decrease the activity of water within the cytoplasm and increase both cell volume and turgor near their prestress values [101]. When the cell adapts to the new environment and fermentation begins, other stressors become relevant, such as the accumulation of organic acids and alcohols, changes in temperature, and acidifies the environment [99]. Rising temperature and/or decreasing $\mathrm{pH}$ are probably the most common environmental factors that starter cultures have to deal with during fermentation processes.

Commercial starter cultures usually come from either food substrates or the processes in which they are applied. Environmental conditions, back-slopping, adaptation and repeated use of similar utensils may help select the microbial communities typical of the fermentation process. The selection of appropriate starter strains should take into account their interactions in mixed cultures, taking into account the behavior of these strains under defined conditions and within the food substrate. Other factors to be considered include: 1) competitive behaviour, viability and survival; 2) antagonism against pathogens and spoilage microbes; 3) the rate of acid or alcohol production; 4) organoleptic changes; 5) primary metabolites of fermentation; 6) degradation of antinutritive factors; 7) detoxification; 8) probiotic features [94].

\subsubsection{Technical Considerations}

Technical aspects of starter culture development should include considerations relevant to the adoption of the starter to the substrate, the acid production rate, fermentation metabolites (e.g. hetero-vs. homofermentation) and the ability of single or mixed strain cultures to produce desirable sensory qualities in the fermented product. many reports indicate that Lactobacillus brevis, L. fermentum, L. plantarum, L. reuteri, Pediococcus pentosaceus and P. acidilactici show superior performance in lactic fermented cereal and vegetable products [94] [102] 
[103] [104] [105]. This is quite possibly the case for root crops, while the initiation of milk fermentations is typically associated with Lactococcus lactis, followed by $L$. casei (paracasei) and other Lactobacillus spp. during maturation. Several LAB are associated with meat and fish fermentations. $L$. sakei and $L$. curvatus [92] have been determined to be superior starter cultures for meat fermentations. Leuconostoc mesenteroides frequently dominates the early stages of most spontaneous fermentations.

Plant materials containing fermentable sugars provide suitable substrates for the yeast species Saccharomyces, Candida, Torula and Hansenula. Although the growth rate of these yeasts is lower than that of bacteria, such as L. mesenteroides, strains of Saccharomyces cerevisiae eventually dominate most spontaneous alcoholic fermentations as in the production of African opaque beers, palm wine and Asian beverages, such as rice wines and Indonesian tape'. Indeed, most traditional fermentations result from the combined metabolic activities of different types of microorganisms. Hounhouigan et al. [106] [107] reported a stimulating effect of the yeast Candida krusei on L. fermentum and L. brevis during a mixed starter culture fermentation of the fermented maize product, mawe.

\subsubsection{Antagonism}

This is the combined effect of different biological factors, resulting from metabolic activities of microorganisms and their competitive interactions. Fermentations involving yeasts (alcoholic fermentations of beer and palm wines), moulds (e.g. tempe fermentations), particular bacilli alkaline fermentations e.g. as for dawadawa (Nigeria and Ghana), soumbala (Burkina Faso), natto (Japan) or kinema (Himalayas) and LAB are generally recognised as safe ("GRAS"). There are no health risks associated with the dominant species of these fermentations. To some extent, these beneficial microorganisms are used to guard against pathogens and spoilage organisms. In particular, lactic fermented foods are considered safe and healthy. On the other hand, in fermented foods, acidification to $\mathrm{pH}$ values below 4.2 is a major safety issue. Nonetheless, recent findings indicate that a number of metabolites, such as acetic acid (from heterofermentative LAB), hydrogen peroxide and bacteriocins generated during the fermentation process, exhibit antimicrobial properties that may contribute to the protection of fermented lactic foods. Organic acids, which show strong antagonistic effects in the undissociated form at lower $\mathrm{pH}$ values, are particularly effective in inhibiting Gram-negative bacteria, such as pathogens.

\subsubsection{Bacteriocins}

Bacteriocins are protein-like antimicrobials that are active against closely related bacteria. They exhibit a narrow range of activity but are not active against Gram-negative bacteria. In food substrates, proteolytic enzymes are capable of inactivating bacteriocins. LAB bacteriocins can be divided into three structural groups based on their physico-chemical and antimicrobial properties [108]. Though relatively uncommon in fermented foods [63], bacteriocinogenic LAB 
strains are of special interest in view of their possible application in food safety assurance. Bacteriocinogenic $\mathrm{LAB}$ has been shown to effectively inhibit the growth of pathogens, such as Listeria monocytogenes, Staphylococcus aureus, Bacillus cereus and Clostridium dificile, even under in situ conditions [108].

\section{Approaches toward Starter Cultures with Improved Properties}

\section{Genetic Improvements: Pro and Contra}

It is doubtful whether the most modern techniques and selection procedures would result in a multifunctional strain having all desirable metabolic features. Selected strains may be improved through the application of genetic technologies. Recombinant DNA engineering may be used in the development of tailor-made starter cultures that would meet the technological and metabolic specifications required for specific fermentation (e.g. accelerated acid output, enhanced wholesomeness, health-promoting properties, overproduction of bacteriocins or particular enzymes needed to remove unwanted factors). Undesirable products, such as mycotoxin and antibiotic development in food grade moulds, may be removed by strategies such as gene destruction [109]. A large number of such optimised cultures already exist. Regulatory issues, however, preclude their application.

\section{Conclusions}

Knowledge of traditional fermentation is rapidly increasing. Studies on microbial dynamics, substrate-related interactions and metabolic activities of various microbial groups, main enzymes and the function of technical and other system parameters have provided a firm basis for improving conventional, small-scale and household fermentation processes. The introduction of appropriate starter culture techniques may constitute one major step towards improved safety, quality and security of traditional small-scale fermentation. Artisanal-level starter culture traditions in Asia have proved feasible for decades and can serve as a model for application in Africa.

Starter culture development and improvement is the subject of much research both in developed and in developing countries. Current literature records volumes of research reports on the characterization of microbes related to the processing of traditional fermented foods in developing countries. Relatively few of these studies document the application of modern biotechnology diagnostic tools to the development and design of starter cultures. In various studies, Ouoba et al. [49] [50] [88] [110] [111] showed the ability of B. subtilis and B. pumilus to degrade African locust bean oil, proteins and carbohydrates, and also their ability to produce a pleasant aroma and antimicrobial substances against pathogens. They have proposed B. subtilis B7 and B15 as suitable starter cultures for the controlled production of soumbala. For ugba production, Sanni et al. [65] suggested strains of $B$. subtilis, especially B. subtilis MM-4:B12, as potential 
starter cultures based on their enzymatic activities and ability to produce stickiness. Amoa-Awua et al. [25] have screened 42 Bacillus isolates from soydawadawa and proposed B. subtilis 24BP2 and B. subtilis FpdP2 as the best starter cultures for soydawadawa production. Further work by Terlabie et al. [112] rated B. subtilis FpdP2 as the best starter culture.

Focused studies on the introduction of starter cultures for small-scale fermentations appear more than justified, and in fact, deserve the highest priority. A number of aspects of relevance to starter culture production should, therefore, receive special attention. As examples, the following should be mentioned. 1) Amino acid decarboxylase activity as a negative selection feature for potential starter cultures and mono-amino-oxidase activity as a positive selection criterion to reduce biogenic amine levels in selected fermented foods. 2) Potential for mycotoxin fermentation, strain selection methods, and toxicological tests on potential degradation products.

\section{Conflicts of Interest}

The authors declare no conflicts of interest regarding the publication of this paper.

\section{References}

[1] Adekoya, I., Obadina, A., Phoku, J., Nwinyi, O. and Njobeh, P. (2017) Contamination of Fermented Foods in Nigeria with Fungi. LWT-Food Science and Technology, 86, 76-84. https://doi.org/10.1016/j.lwt.2017.07.044

[2] Kavitakea, D., Kandasamya, S., Devib, P.B. and Shettya, P.H. (2017) Recent Developments on Encapsulation of Lactic Acid Bacteria as Potential Starter Culture in Fermented Foods-A Review. Food Bioscience, 21, 34-44. https://doi.org/10.1016/j.fbio.2017.11.003

[3] Chilton, S., Burton, J. and Reid, G. (2015) Inclusion of Fermented Foods in Food Guides around the World. Nutrients, 7, 390-404. https://doi.org/10.3390/nu7010390

[4] Oyewole, O.A. and Isah, P. (2012) Locally Fermented Foods in Nigeria and Their Significance to National Economy: A Review. Journal of Recent Advances in Agriculture, 1, 92-102.

[5] Babajide, J.M., Obadina, A.O., Oyewole, O.B. and Ugbaka, L.N. (2006) Microbial Quality of Dry Yam "Gbodo" Parboiled with/without Adjuncts. African Journal of Biotechnology, 5, 278-281.

[6] Hutkins, R.W. (2006) Microbiology and Biotechnology of Fermented Foods. Blackwell Publishing, Hoboken. https://doi.org/10.1002/9780470277515

[7] Tamang, J.P., Watanabe, K. and Holzapfel, W.H. (2016) Review: Diversity of Microorganisms in Global Fermented Foods and Beverages. Frontiers in Microbiology, 7, 377. https://doi.org/10.3389/fmicb.2016.00377

[8] Johansen, E. (2018) Use of Natural Selection and Evolution to Develop New Starter Cultures for Fermented Foods. Annual Review of Food Science and Technology, 9 , 411-428. https://doi.org/10.1146/annurev-food-030117-012450

[9] Achi, O.K. (1999) Quality Attributes of Fermented Yam Flour Supplemented with Processed Soy Flour. Plant Foods for Human Nutrition, 54, 151-158. https://doi.org/10.1023/A:1008130218830 
[10] Achi, O.K. (2005) Traditional Fermented Protein Condiments in Nigeria. African Journal of Biotechnology, 4, 13.

[11] Campbell-Platt, G. (1980) African Locust Bean (Parkia Species) and Its West African Fermented Food Product, Dawadawa. Ecology of Food and Nutrition, 9, 123-132. https://doi.org/10.1080/03670244.1980.9990590

[12] Odunfa, S.A. (1985) Biochemical Changes in Fermenting African Locust Bean (Parkia biglobosa) during "Iru" Fermentation. International Journal of Food Science \& Technology, 20, 295-303. https://doi.org/10.1111/j.1365-2621.1985.tb00379.x

[13] Aidoo, K.E. (1986) Lesser-Known Fermented Plant Foods. Tropical Sciences, 26, 249-258.

[14] Achi, O.K. (1992) Microorganisms Associated with Natural Fermentation of Prosopis africana Seeds for the Production of Okpiye. Plant Foods for Human Nutrition, 42, 297-304. https://doi.org/10.1007/BF02194090

[15] Oniofiok, N., Nnayelugo, D.O. and Ukwondi, B.E. (1996) Usage Patterns and Contributions of Fermented Foods to the Nutrient Intake of Low-Income Households in Emene Nigeria. Plant Foods Human Nutrition, 49, 199-211. https://doi.org/10.1007/BF01093216

[16] Fetuga, B.L., Babatunde, G.M. and Oyenuga, V.A. (1973) Protein Quality of Some Nigerian Feed Stuffs. II. Biological Evaluation of Protein Quality. Journal of the Science of Food and Agriculture, 24, 1515-1523. https://doi.org/10.1002/jsfa.2740241207

[17] Eka, O.U. (1980) Effect of Fermentation on the Nutrient Status of Locust Beans. Food Chemistry, 5, 303-308. https://doi.org/10.1016/0308-8146(80)90051-5

[18] Reddy, N.R. and Pierson, M.D. (1999) Reduction in Antinutritional and Toxic Components in Plant Foods by Fermentation. Food Research International, 27, 281-290. https://doi.org/10.1016/0963-9969(94)90096-5

[19] Barimalaa, I.S., Achinewhu, S.C., Yibatima, I. and Amadi, E.N. (1994) Studies on the Solid Substrate Fermentation of Bambara Groundnut (Vigna subterranea (L) Verdc). Journal Science of Food Agriculture, 66, 443-446. https://doi.org/10.1002/jsfa.2740660404

[20] Achi, O.K. and Okereka, E.G. (1999) Proximate Composition and Functional Properties of Prosopis africana Seed Flour. Journal of Management Technology, 1, 7-13.

[21] Holzapfel, W.H. (2002) Appropriate Starter Culture Technologies for Small-Scale Fermentation in Developing Countries. International Journal of Food Microbiology, 75, 197-212. https://doi.org/10.1016/S0168-1605(01)00707-3

[22] Hammes, W.P. (1990) Bacterial Starter Cultures in Food Production. Food Biotechnology, 4, 383-397. https://doi.org/10.1080/08905439009549750

[23] Iwuoha, C.I. and Eke, O.S. (1996) Nigerian Indigenous Fermented Foods: Their Traditional Process Operation, Inherent Problems, Improvements and Current Status. Food Research International, 29, 527-540. https://doi.org/10.1016/0963-9969(95)00045-3

[24] Ouoba, L.I.I., Thorsen, L. and Varnam, A.H. (2008) Enterotoxins and Emetic Toxins Production by Bacillus cereus and Other Species of Bacillus Isolated from Soumbala and Bikalga, African Alkaline Fermented Food Condiments. International Journal of Food Microbiology, 124, 224-230. https://doi.org/10.1016/j.ijfoodmicro.2008.03.026

[25] Amoa-Awua, W.K., Terlabie, N.N. and Sakyi-Dawson, E. (2006) Screening of 42 Bacillus Isolates for Ability to Ferment Soybeans into Dawadawa. International 
Journal of Food Microbiology, 106, 343-347.

https://doi.org/10.1016/j.ijfoodmicro.2005.08.016

[26] Meerak, J., Yukphan, P., Miyashita, M., Sato, H., Nakagawa, Y. and Tahara, Y. (2008) Phylogeny of $\gamma$-Polyglutamic Acid-Producing Bacillus Strains Isolated from a Fermented Locust Bean Product Manufactured in West Africa. The Journal of General and Applied Microbiology, 54, 159-166.

https://doi.org/10.2323/jgam.54.159

[27] Odunfa, S.A. and Oyewole, O.B. (1998) African Fermented Foods. In: Wood, B.J.B., Ed., Microbiology of Fermented Foods, 2nd Edition, Vol. 2, Blackie Academic and Professional, London, 713-752. https://doi.org/10.1007/978-1-4613-0309-1_23

[28] Oguntoyinbo, F.A., Huch, M., Cho, G.S., Schillinger, U., Holzapfel, W.H., Sanni, A.I. and Franz, C.M. (2010) Diversity of Bacillus Species Isolated from Okpehe, a Traditional Fermented Soup Condiment from Nigeria. Journal of Food Protection, 73, 870-878. https://doi.org/10.4315/0362-028X-73.5.870

[29] Odibo, F.J.C., Ugwu, D.A. and Ekeocha, D.C. (1992) Microorganisms Associated with the Fermentation of Prosopis Seeds for Ogiri-Okpei Production. Journal of Food Science and Technology. Mysore, 29, 306-307.

[30] Sanni, A.I. (1993) The Need for Process Optimization of African Fermented Foods and Beverages. International Journal of Food Microbiology, 18, 85-95.

https://doi.org/10.1016/0168-1605(93)90213-Z

[31] Ouoba, L.I.I., Diawara, B., kofi Amoa-Awua, W., Traoré, A.S. and Møller, P.L. (2004) Genotyping of Starter Cultures of Bacillus subtilis and Bacillus pumilus for Fermentation of African Locust Bean (Parkia biglobosa) to Produce Soumbala. International Journal of Food Microbiology, 90, 197-205.

https://doi.org/10.1016/S0168-1605(03)00302-7

[32] Ahaotu, I., Anyogu, A., Njoku, O.H., Odu, N.N., Sutherland, J.P. and Ouoba, L.I.I. (2013) Molecular Identification and Safety of Bacillus Species Involved in the Fermentation of African Oil Beans (Pentaclethra macrophylla Benth) for Production of Ugba. International Journal of Food Microbiology, 162, 95-104.

https://doi.org/10.1016/j.ijfoodmicro.2013.01.001

[33] Ogbonna, D.N., Sokari, T.G. and Achinewhu, S.C. (2001) Development of an Owoh-Type Product from African Yam Beans (Sphenostylis stenocarpa) (Hoechst (ex. A. Rich.) Harms.) Seeds by Solid Substrate Fermentation. Plant Foods for Human Nutrition, 56, 183-194. https://doi.org/10.1023/A:1011185513717

[34] Sanni, A.I. and Ogbonna, D.N. (1991) The Production of Owoh-A Nigerian Fermented Seasoning Agent from Cotton Seed (Gossypium hirsutum L.). Food Microbiology, 8, 223-229. https://doi.org/10.1016/0740-0020(91)90054-6

[35] Jeff-Agboola, Y.A. (2007) Microorganisms Associated with Natural Fermentation of African Yam Bean (Sphenostylis sternocarpa Harms) Seeds for the Production of Otiru. Research Journal of Microbiology, 2, 816-823. https://doi.org/10.3923/jm.2007.816.823

[36] Mohamadou, B.A., Mbofung, C.M. and Barbier, G. (2013) Genotypic and Phenotypic Diversity among Bacillus Species Isolated from Mbuja, a Cameroonian Traditional Fermented Condiment. African Journal of Biotechnology, 12, 1335-1343.

[37] Parkouda, C., Nielsen, D.S., Azokpota, P., Ivette Irène Ouoba, L., Amoa-Awua, W.K., Thorsen, L. and Jakobsen, M. (2009) The Microbiology of Alkaline-Fermentation of Indigenous Seeds Used as Food Condiments in Africa and Asia. Critical Reviews in Microbiology, 35, 139-156. https://doi.org/10.1080/10408410902793056

[38] Akabanda, F., Parkouda, C., Suurbaar, J. Addai-Mensah, D. and Owusu-Kwarteng, 
J. (2018) Effects of Mechanical Dehulling on Microbiological Characteristics and Chemical Changes during Processing of Parkia biglobosa Seeds into Dawadawa, a West African Alkaline Fermented Condiment. Journal of Ghana Science Association, 2, 14-19.

[39] Ezeokoli, O.T., Adeleke, R.A. and Bezuidenhout, C.C. (2018) Core Bacterial Community of Soy-Daddawa: Insights from High-Throughput DNA Metabarcoding. LWT-Food Science and Technology, 97, 61-66.

https://doi.org/10.1016/j.lwt.2018.06.039

[40] Sanni, A.I., Ayernor, G.S., Sakyi-Dawson, E. and Sefa-Dedeh, S. (2000) Aerobic Spore-Forming Bacteria and Chemical Composition of Some Nigerian Fermented Soup Condiments. Plant Foods for Human Nutrition, 55, 111-118. https://doi.org/10.1023/A:1008147120526

[41] Diawara, B., Sawadogo, L. and Kabore, I.Z. (1992) Contribution a l'etude des procedes traditionnels de fabrication du soumbala au Burkina Faso. Aspects biochimiques, microbiologiques et technologiques. Sciences et Techniques, 20, 5-14.

[42] N’Dir, B., Hbid, C., Cornélius, C., Roblain, D., Jacques, P., Vanhentenryck, F. and Thonart, P. (1994) Propriétés antifongiques de la microflore sporulée du "nététu". Cahiers Agricultures, 3, 23-30.

[43] Azokpota, P., Hounhouigan, D.J. and Nago, M.C. (2006) Microbiological and Chemical Changes during the Fermentation of African Locust Bean (Parkia biglobosa) to Produce Afitin, Iru and Sonru, Three Traditional Condiments Produced in Benin. International Journal of Food Microbiology, 107, 304-309. https://doi.org/10.1016/j.ijfoodmicro.2005.10.026

[44] Beaumont, M. (2002) Flavouring Composition Prepared by Fermentation with Bacillus spp. International Journal of Food Microbiology, 75, 189-196. https://doi.org/10.1016/S0168-1605(01)00706-1

[45] Dakwa, S., Sakyi-Dawson, E., Diako, C., Annan, N.T. and Amoa-Awua, W.K. (2005) Effect of Boiling and Roasting on the Fermentation of Soybeans into Dawadawa (Soy-Dawadawa). International Journal of Food Microbiology, 104, 69-82. https://doi.org/10.1016/j.ijfoodmicro.2005.02.006

[46] Odunfa, S.A. and Adewuyi, E.Y. (1985) Optimization of Process Conditions for the Fermentation of African Locust Bean (Parkia biglobosa) II. Effect of Starter Cultures. Chemie, Mikrobiologie, Technologie der Lebensmittel, 9, 118-122.

[47] Akaaimo, D.I. and Raji, A.O. (2006) Some Physical and Engineering Properties of Prosopis africana Seed. Biosystems Engineering, 95, 197-205. https://doi.org/10.1016/j.biosystemseng.2006.06.005

[48] Odunfa, S.A. (1988) African Fermented Foods: From Art to Science. MIRCEN Journal of Applied Microbiology and Biotechnology, 4, 259-273.

https://doi.org/10.1007/BF01096132

[49] Ouoba, L.I.I., Cantor, M.D., Diawara, B., Traore, A.S. and Jakobsen, M. (2003) Degradation of African Locust Bean Oil by Bacillus subtilis and Bacillus pumilus Isolated from Soumbala, a Fermented African Locust Bean Condiment. Journal of Applied Microbiology, 95, 868-873. https://doi.org/10.1046/j.1365-2672.2003.02063.x

[50] Ouoba, L.I.I., Rechinger, K.B., Barkholt, V., Diawara, B., Traore, A.S. and Jakobsen, M. (2003) Degradation of Proteins during the Fermentation of African Locust Bean (Parkia biglobosa) by Strains of Bacillus subtilis and Bacillus pumilus for Production of Soumbala. Journal of Applied Microbiology, 94, 396-402. https://doi.org/10.1046/j.1365-2672.2003.01845.x

[51] Diawara, B. and Diasso, K. (2004) Bilan de matières dans le procédé traditionnel de 
production du Soumbala. Valorisation technologique et nutritionnelle du néré ou Parkia biglobosa, 133-142.

[52] Sawadogo-Lingani, H., Diawara, B., Ganou, L., Gouyahali, S., Halm, M., Amoa-Awua, W. and Jakobsen, M. (2003) Effet du decorticage mécanique sur la fermentation des graines de nere Parkia biglobosa, en soumbala. Annales des Sciences Agronomiques du Benin, 5, 67-84.

[53] Akande, F.B., Adejumo, O.A., Adamade, C.A. and Bodunde, J. (2010) Processing of Locust Beans Fruits: Challenges and Prospects. African Journal of Agricultural Research, 5, 2268-2271.

[54] Oyewole, O.B. and Odunfa, S.A. (1990) Effect of Cooking Method on Water Absorption and Ease of Dehulling in Preparation of African Locust Beans for Iru. International Journal of Food Science \& Technology, 25, 461-463.

https://doi.org/10.1111/j.1365-2621.1990.tb01104.x

[55] Adewumi, B.A. and Olalusi, A.P. (2005) Performance of a Manually Operated Concave Type Locust Bean Dehuller. Journal of Agriculture Technology, 6, 23-30.

[56] Alabi, D.A., Akinsulire, O.R. and Sanyaolu, M.A. (2005) Qualitative Determination of Chemical and Nutritional Composition of Parkia biglobosa (Jacq.) Benth. African Journal of Biotechnology, 4, 812-815.

[57] Audu, I., Oloso, A.O. and Umar, B. (2004) Development of a Concentric Cylinder Locust Bean Dehuller. Agricultural Engineering International: CIGR Journal, 6, $1-11$.

[58] Traore, Z., Son, G. and Diawara, B. (2004) Decorticage mecanique des graines de nere. Valorisation technologique et nutritionnelle du nere ou Parkia biglobosa (Jacq.) Benth: Une espece agro forestiere. Diawara B. et Jakobsen M.

[59] Tchongdjeu, Z., Weber, J. and Guarino, L. (1998) Germplasm Collections of Endangered Agroforestry Tree Species: The Case of Prosopis africana in the Semi Arid Low Lands of West Africa. Agroforestry Systems, 39, 91-100. https://doi.org/10.1023/A:1005887706700

[60] Sanni, A.I. and Onilude, A.A. (1999) Characterization of Bacillus Species Isolated from Okpehe, a Fermented Soup Condiment from Prosopis africana. Nigeria Journal of Sciences, 31, 49-52.

[61] Oguntoyinbo, F.A., Sanni, A.I., Franz, C.M. and Holzapfel, W.H. (2007) In Vitro Fermentation Studies for Selection and Evaluation of Bacillus Strains as Starter Cultures for the Production of Okpehe, a Traditional African Fermented Condiment. International Journal of Food Microbiology, 113, 208-218.

https://doi.org/10.1016/j.ijfoodmicro.2006.07.006

[62] Obeta, J.A.N. and Ugwuanyi, M.A.A. (1996) Microbiology of the Production of Okpeye, a Condiment from Seeds of Prosopis africana Taub. Tropical Science (United Kingdom), 36, 206-210.

[63] Olasupo, N.A., Okorie, C.P. and Oguntoyinbo, F.A. (2016) The Biotechnology of Ugba, a Nigerian Traditional Fermented Food Condiment. Frontiers in Microbiology, 7, 1153. https://doi.org/10.3389/fmicb.2016.01153

[64] Ikenebomeh, M.J., Kok, R. and Ingram, J.M. (1986) Processing and Fermentation of the African Locust Bean (Parkia filicoidea Welw.) to Produce Dawadawa. Journal of the Science of Food and Agriculture, 37, 273-282.

https://doi.org/10.1002/jsfa.2740370312

[65] Sanni, A.I., Morlon-Guyot, J. and Guyot, J.P. (2002) New Efficient Amylase-Producing Strains of Lactobacillus plantarum and L. fermentum Isolated from Different Nigerian Traditional Fermented Foods. International Journal of Food Microbiology, 72, 
53-61. https://doi.org/10.1016/S0168-1605(01)00607-9

[66] Ogueke, C.C., Nwosu, J.N., Owuamanam, C.I. and Iwouno, J.N. (2010) Ugba, the Fermented African Oil Bean Seeds; Its Production, Chemical Composition, Preservation, Safety and Health Benefits. Pakistan Journal of Biological Sciences, 13, 489-496. https://doi.org/10.3923/pjbs.2010.489.496

[67] Nwokeleme, C.O. and Ugwuanyi, J.O. (2015) Evolution of Volatile Flavour Compounds during Fermentation of African Oil Bean (Pentaclethra macrophylla Benth) Seeds for "Ugba" Production. International Journal of Food Science, 2015, Article ID: 706328. https://doi.org/10.1155/2015/706328

[68] Obeta, J.A.N. (1983) A Note on the Micro-Organisms Associated with the Fermentation of Seeds of the African Oil Bean Tree (Pentaclethra macrophylla). Journal of Applied Bacteriology, 54, 433-435. https://doi.org/10.1111/j.1365-2672.1983.tb02639.x

[69] Odunfa, S.A. and Oyeyiola, G.P. (1985) Microbiology Study of the Fermentation of Ugba. Journal of Plant Foods, 6, 155-163.

https://doi.org/10.1080/0142968X.1985.11904309

[70] Njoku, H.O. and Okemadu, C.P. (1989) Biochemical Changes during the Natural Fermentation of the African Oil Bean (Pentaclethra macrophylla) for the Production of Ugba. Journal of the Science of Food and Agriculture, 49, 457-465. https://doi.org/10.1002/jsfa.2740490408

[71] Sokari, T.G. and Wachukwu, C.K. (1997) Simple Rapid Processing of African Oil Bean Seeds for Ugba Production. International Journal of Food Science and Technology, 32, 77-79. https://doi.org/10.1046/j.1365-2621.1997.00371.x

[72] Omafuvbe, B.O. and Kolawole, D.O. (2004) Quality Assurance of Stored Pepper (Piper guineense) Using Controlled Processing Methods. Pakistan Journal of Nutrition, 3, 244-249. https://doi.org/10.3923/pjn.2004.244.249

[73] Sanni, A. I. (1993) The Need for Process Optimization of African Fermented Foods and Beverages. International of Food Microbiology, 18, 85-95.

https://doi.org/10.1016/0168-1605(93)90213-Z

[74] Abu-Tarboush, H.M., Ahmed, S.A.B. and Al Kahtani, H.A. (1997) Some Nutritional and Functional Properties of Karkade (Hibiscus sabdariffa) Seed Products. Cereal Chemistry, 74, 352-355. https://doi.org/10.1094/CCHEM.1997.74.3.352

[75] Yagoub, A.E.G.A., Mohamed, B.E., Ahmed, A.H.R. and El Tinay, A.H. (2004) Study on Furundu, a Traditional Sudanese Fermented Roselle (Hibiscus sabdariffa L.) Seed: Effect on in Vitro Protein Digestibility, Chemical Composition, and Functional Properties of the Total Proteins. Journal of Agricultural and Food Chemistry, 52, 6143-6150. https://doi.org/10.1021/jf0496548

[76] Aderibige, E.Y. and Odunfa, S.A. (1990) Growth and Extracellular Enzyme Production by Strains of Bacillus Species Isolated from Fermenting African Locust Bean, Iru. Journal of Applied Bacteriology, 69, 662-671. https://doi.org/10.1111/j.1365-2672.1990.tb01560.x

[77] Sarker, P.K., Jones, I.J., Craven, G.S. and Somerset, S.M. (1997) Oligosaccharide Profiles of Soybeans during Kinema Production. Letter of Applied Microbiology, 24, 337-339. https://doi.org/10.1046/j.1472-765X.1997.00035.x

[78] Omafuvbe, B.O., Shonukan, O.O. and Abiose, S.H. (2000) Microbiological and Biochemical Changes in the Traditional Fermentation of Soybean for "Soy-Daddawa" -Nigerian Food Condiment. Food Microbiology, 17, 469-474.

https://doi.org/10.1006/fmic.1999.0332

[79] Kiers, J.L., Rombouts, F.M. and Nout, M.J.R. (2000) In Vitro Digestibility of Bacil- 
lus Fermented Soya Bean. International Journal of Food Microbiology, 60, 163-169. https://doi.org/10.1016/S0168-1605(00)00308-1

[80] Irvine, F.R. (1961) Woody Plants of Ghana.

[81] Winarno, F.G. and Reddy, N.R. (1986) Tempe. In: Reddy, N.R., Pierson, M.D. and Salunkhe, D.K., Eds., Legume-Based Fermented Foods, CRC Press, Boca Raton, 95-117.

[82] Fardiaz, D. and Markakis, P. (1981) Degradation of Phytic Acid in Oncom (Fermented Peanut Press Cake). Journal of Food Science, 46, 523-525.

https://doi.org/10.1111/j.1365-2621.1981.tb04901.x

[83] Whitaker, J.R. (1978) Biochemical Changes during the Fermentation of High Protein Foods. Food Technology, 32, 175-190.

[84] Barber, L.I. and Achinewhu, S.C. (1992) Microbiology of Ogiri Production from Melon Seeds (Citrullus vulgaris).Nigerian Food Journal, 10, 129-135.

[85] Achinewhu, S.C. (1987) Protein Quality Evaluation of Weaning Food Mixtures from Indigenous Fermented Foods. Nigeria Journal of Nutritional Sciences, 8, 23-31.

[86] Nout, M.J.R. and Rombouts, F.M. (1990) Recent Developments in Tempe Research. Journal of Applied Bacteriology, 69, 609-633. https://doi.org/10.1111/j.1365-2672.1990.tb01555.x

[87] Young, F.M. and Wood, B.J. (1997) Microbiology and Biochemistry of Soy-Sauce Fermentation. Advanced Applied Microbiology, 17, 157-194.

https://doi.org/10.1016/S0065-2164(08)70558-6

[88] Ouoba, L.I.I., Diawara, B., Annan, N.T., Poll, L. and Jakobsen, M. (2005) Volatile Compounds of Soumbala, a Fermented African Locust Bean (Parkia biglobosa) Food Condiment. Journal of Applied Microbiology, 99, 1413-1421. https://doi.org/10.1111/j.1365-2672.2005.02722.x

[89] Darweesh, L.L., Toma, R.B., Lee, H.C. and Weiss, T.J. (1991) Chemical and Sensory Evaluation of Lipid Blends Used in Pie Crusts. Food Chemistry, 39, 87-98. https://doi.org/10.1016/0308-8146(91)90087-5

[90] Arogba, S.S., Ademola, A. and Elum, M. (1995) The Effect of Solvent Treatment on the Chemical Composition and Organoleptic Acceptability of Traditional Condiments from Nigeria. Plant Foods for Human Nutrition, 48, 31-38.

https://doi.org/10.1007/BF01089197

[91] Obizoba, I.C. (1998) Fermented Foods. In: Nutritional Quality of Plant Foods, University of Benin, Benin City, 160-198.

[92] Hammes, W.P. and Hertel, C. (1998) New Developments in Meat Starter Cultures. Meat Science, 49, 125-138.https://doi.org/10.1016/S0309-1740(98)90043-2

[93] Laranjo, M., Elias, M. and Fraqueza, M.J. (2017) The Use of Starter Cultures in Traditional Meat Products. Journal of Food Quality, 2017, Article ID: 9546026. https://doi.org/10.1155/2017/9546026

[94] Holzapfel, W.H. (1997) Use of Starter Cultures in Fermentation on a Household Scale. Food Control, 8, 241-258.https://doi.org/10.1016/S0956-7135(97)00017-0

[95] Adegoke, G.O., Otumu, E.J. and Akanni, A.O. (1994) Influence of Grain Quality, Heat, and Processing Time on the Reduction of Aflatoxin B1 Levels in "Tuwo" and "Ogi”: Two Cereal-Based Products. Plant Foods for Human Nutrition, 45, 113-117. https://doi.org/10.1007/BF01088468

[96] Smith, J.E., Lewis, C.W. anderson, J.G. and Solomons, G.L. (1994) Mycotoxins in Human Nutrition and Health. European Union Directorate-General XII, Report 
$16048 \mathrm{EN}$.

[97] Westby, A., Reilly, A. and Bainbridge, Z. (1997) Review of the Effect of Fermentation on Naturally Occurring Toxins. Food Control, 8, 329-339.

https://doi.org/10.1016/S0956-7135(97)00003-0

[98] Gilberto, V.P., Dão, P.C.N., Ana, C.D.O.J., Susan, G.K., Luiz, A.J.L., Antonio, I.M.J. and Carlos, R.S. (2019) A Review of Selection Criteria for Starter Culture Development in the Food Fermentation Industry.Food Reviews International, 36, 135-167.

[99] Yousef, A.E. and Courtney, P.D. (2003) Basics of Stress Adaptation and Implications in New-Generation Foods. In: Yousef, A.E. and Juneja, V.K., Eds.,Microbial Stress Adaptation and Food Safety, CRC Press, Boca Raton, 1-30.

[100] Bauer, F.F. and Pretorius, I.S. (2000) Yeast Stress Response and Fermentation Efficiency: How to Survive the Making of Wine-A Review. South African Journal for Enology and Viticulture, 21, 27-46.https://doi.org/10.21548/21-1-3557

[101] Csonka, L.N. (1989) Physiological and Genetic Responses of Bacteria to Osmotic Stress. Microbiology Review, 53, 121-147. https://doi.org/10.1128/MMBR.53.1.121-147.1989

[102] Steinkraus, K.H. (1996) Handbook of Indigenous Fermented Foods. 2nd Edition, Marcel Dekker, New York.

[103] Steinkraus, K.H. (1997) Classification of Fermented Foods: Worldwide Review of Household Fermentation Techniques. Food Control, 8, 311-317. https://doi.org/10.1016/S0956-7135(97)00050-9

[104] Lee, C.-H. (1997) Lactic Acid Fermented Foods and Their Benefits in Asia. Food Control, 8, 259-269.https://doi.org/10.1016/S0956-7135(97)00015-7

[105] Oyewole, O.B. (1997) Lactic Fermented Foods in Africa and Their Benefits. Food Control, 8, 289-297.https://doi.org/10.1016/S0956-7135(97)00075-3

[106] Hounhouigan, D.J., Nout, M.J.R., Nago, C.M., Houben, J.H. and Rombouts, F.M. (1993) Changes in the Physio-Chemical Properties of Maize during Natural Fermentation of Mawe. Journal of Cereal Science, 17, 291-300.

https://doi.org/10.1006/jcrs.1993.1027

[107] Hounhouigan, D.J., Nout, M.J.R., Nago, C.M., Houben, J.H. and Rombouts, F.M. (1999) Use of Starter Cultures of Lactobacilli and Yeast in the Fermentation of Mawe, an African Maize Product. Tropical Science,39, 220-226.

[108] Holzapfel, W.H., Geisen, R. and Schillinger, U. (1995) Biological Preservation of Foods with Reference to Protective Cultures, Bacteriocins and Food-Grade Enzymes. International Journal of Food Microbiology,24, 343-362. https://doi.org/10.1016/0168-1605(94)00036-6

[109] Geisen, R. and Holzapfel, W.H. (1996) Genetically Modified Starter and Protective Cultures. International Journal of Food Microbiology,30, 315-324.

https://doi.org/10.1016/0168-1605(96)00959-2

[110] Ouoba, L.I.I., Diawara, B., Jespersen, L. and Jakobsen, M. (2007) Antimicrobial Activity of Bacillus subtilis and Bacillus pumilus during the Fermentation of African Locust Bean (Parkia biglobosa) for Soumbala Production. Journal of Applied Microbiology, 102, 963-970.

[111] Ouoba, L.I.I., Diawara, B., Christensen, T., Mikkelsen, J.D. and Jakobsen, M. (2007) Degradation of Polysaccharides and Non-Digestible Oligosaccharides by Bacillus subtilis and Bacillus pumilus Isolated from Soumbala, a Fermented African Locust Bean (Parkia biglobosa) Food Condiment. European Food Research and Technology, 224, 689-694.https://doi.org/10.1007/s00217-006-0359-0 
[112] Terlabie, N.N., Sakyi-Dawson, E. and Amoa-Awua, W.K. (2006) The Comparative Ability of Four Isolates of Bacillus subtilis to Ferment Soybeans into Dawadawa. International Journal of Food Microbiology, 106, 145-152.

https://doi.org/10.1016/j.ijfoodmicro.2005.05.021 